\title{
Highly Efficient Magnetic Phosphoric Acid Modified Defatted Chlorella Vulgaris Algae ( MDCV/Fe304) as a Novel Biosorbent for Methylene Blue Removal
}

\section{Research}

Keywords:

Posted Date: April 26th, 2021

DOI: https://doi.org/10.21203/rs.3.rs-136792/v2

License: (c) (1) This work is licensed under a Creative Commons Attribution 4.0 International License.

Read Full License 


\section{Abstract}

The authors have requested that this preprint be withdrawn due to author disagreement.

\section{Full Text}

The authors have withdrawn this preprint from Research Square. 